\title{
Waiata-ā-ringa
}

\section{Will waiata-ā-ringa replace classical chant in the new century?}

\section{E Pari Rā}

E pari rā ngā tai ki te ākay

E hotu rā ko taku manawa

Aue, me tangi noa

Ahau i muri nei

Tēnei rā ahau te tangi nei

Mōhou kua wehe nei

Let the waves flow to the shore

And let my heart throb with the pain

Let me weep

Here at home

I am weeping

For you, now departed

Ngaro noa koe, e tama

I ngã marae nei

Ko te aroha, e tama,

$E$ pēhi kino nei

Kei Ihipa koe, e tama,

Kei Karipori rā

Kei Paranehe koe, e tama,

Haere, haere rā

You are no longer seen, my son,

On the marae

However, great pain, my son

Gnaws within

You are in Egypt, my son

In Gallipoli

In France, my son

So farewell, farewell.

\section{Hitara Waha Huka}

Hītara waha huka, ūpoko mārō He tangata tohetohe ki te riri e Hinga atu, hinga mai ki runga o Rūhia Ka purari ana mahi, e auē.

Tūkikitia rā, tūhapainga mai

Te rau o tō patu ki runga ki te ūpoko

Hoatu, e tama, karia te kauwae

O te pürari paka nei a Hītara e.

Kua rongo Matarini kua tata tonu mai

A Te Hokowhitu Toa ki Rōma e

Hiki nuku, hiki rangi

Kore rawa he rerenga

$\mathrm{Ka}$ wiri ana papa i te mataku e

Frothy mouthed, hard-headed Hitler

Persists in fighting

Even though soundly defeated in Russia

His acts are unforgivable.

So raise aloft

The blade of your patu to strike his head

Give it to him, soldier, on the jaw

Of this bloody bugger, Hitler.

Mussolini has heard that the arrival is imminent

Of the Māori Battalion in Rome.

No matter which way he turns

There is no escape

His knees quake with fear.

\section{TIMOTI S KARETU}

Professor Kāretu (Tuhoe) is the Māori Language Commissioner and nominated 1995 as Māori Language Year. He was for many years Professor of Māori Studies at Waikato University where he built up a department with strengths in the teaching of the Māori Language. In a recent publication, Haka, the dance of a noble people (Reed, 1993), he draws on deep knowledge of Māori language and culture. This seminar was given at the Stout Research Centre, on 7 June.

I never cease to be amazed at the fact that many of the young people today, who are actively involved in the field of Māori language and custom, prefer to accompany whaikorero with waiata, performed in the traditional unison style, to waiata-ā-ringa the contemporary action song with the rhythms and harmonies so attractive to the ear.

In traditional chant many of the references and allusions are unknown and uncomprehended therefore one might consider them to be unappealing to the young people for that reason, but such would not seem to be the case.

In recent generations waiata-ā-ringa were in the ascendant and the older waiata on the decline with the exception of the tribal areas of Te Arawa, Mātaatua and certain parts of Ngāti Porou. I say 'certain' with regard to the area of Ngāti Porou because the marae of Tokomaru Bay, territory of Tuini Ngāwai the composer whose songs dominated the war years 1939-45, very rarely, if ever, sing traditional chants after whaikōrero but rather, sing the songs of Tuini Ngāwai and more recently those of her niece, Ngoi Pēwhairangi. North of Tokomaru, in and around Ruatōrea, traditional waiata are still performed.

Waiata-ā-ringa, an integral and extremely popular part of the Mãori dance arts are almost a century old. Since their introduction into the Māori dance arts waiata-ā-ringa have assumed the role of several song types of the traditional and classical repertoire - pātere, mōteatea, kaioraora, waiata aroha, and waiata whaiāipo.

History tells us that the action song owes its genesis to Sir Apirana Ngata and Te Puea Hērangi. The story is told of a Cook Island group visiting the marae of Te Puea. She was so taken by the performance of the action songs of the Cook Islanders that she was convinced that they could be adapted to suit the Mãori. It is interesting to note that many of the tunes of early waiata-ā-ringa were borrowed from the Cook Islands, with the tempi changed to suit that of the Mãori. 
From about World War One onwards the waiata-ā-ringa began to be performed more widely with tribal variations mainly in the foot action and some of the hand movements: from the swinging pōwhiri tempo of the Eastern tribes, almost a waltz time, to the western seaboard where the foot does not leave the ground and where the hand movements are not as expansive. Other minor variations are to be found that fall between these two extremes but, overall, the waiata$\bar{a}$-ringa has national currency and is enjoyed by all who hear and see it being performed.

The early songs of encouragement and the laments for those who did not return from the battle field were remembered in song as they had been in traditional society. Paraire Tomoana's lament for the son of Pohau Ellison killed in World War One is still sung today and still performed with the reverence that is its due. In fact 'E Pari Ra' (Example 1) can even be heard being played by pipe and brass bands on very ceremonial occasions which must, surely, be a mark of its acceptance as a song of Aotearoa.

There is a poignancy about the lyric which makes the song very appropriate for those occasions tinged with sadness.

During World War One there were songs which called on the Mãori people to rally to the cause and rally they did. Such songs as 'Te Ope Tuatahi' which describes the different companies and the tribes which comprised them are, in their own way, historical documents, just as many of the chants of the traditional repertoire are.

Sir Apirana Ngata had actively encouraged the building of carved houses throughout the country and many of them were completed during the twenties and thirties, such famous houses as Mahinārangi, Tūrangawaewae (1929); Te Poho-o-Rāwiri, Gisborne (1934); Te Hono-ki-Rarotonga, Tokomaru Bay (1934); Tūkākī, Te Kaha (1940) and Te Ika-aMāui, Waitara (1936). It was edifices such as these that were to encourage the revival of the arts of tukutuku, kōwhaiwhai and whāriki, all of which are assured today and which are to be seen in all their glory and beauty in the carved houses of the last decade or so.

In tandem with the revival of the arts mentioned previously, was the composition of songs to welcome the guests to the very formal opening ceremonies of these houses. Some of these still enjoy currency today in particular, 'Karangatia $\mathrm{Ra}^{\prime}$. It was one of the earlier compositions of Tuini Ngāwai and was sung to welcome the guests to the opening of $\mathrm{Te}$ Hono-ki-Rarotonga, Tokomaru Bay in 1934.

The song expresses all the sentiments considered appropriate for such a formal occasion. It welcomes all the guests, it states the reason for the hui, it expresses sadness for those who have passed on and acknowledges Sir Apirana for his driving inspiration.

Not too many years later World War Two began and, in my opinion, brought with it the 'golden age' of the waiata-ā-ringa. Songs were composed to farewell those who went into 'the
3. Pōwhiritia

I Pōwhiritia rā ngā mōrehu Te iwi tangihia Kua hoki mai ngã tamariki toa Ki te ao ora e.

$\grave{C} H$ Hoki mai rã, hoki mai rā ki te kāinga Te tatari atu nei ki a koutou Ngā tau roa i ngaro atu ai Te aroha e ngau kino nei i ahau

II Ngā whare pã tēnā haukina Te iwi kia koa Te mame me te pōuri nui Tēnei rā kua mahea

\section{Welcome home the survivors} All tribes, pay them your respects The young warriors have returned To the world of the living Welcome, welcome home How we have waited for you These long years you have been away Ah! how the sadness gnaws within. The houses closed for so long, open your doors All tribes, celebrate!

The pain and the sorrow On this day are dispelled.

\section{Whakarongo}

Whakarongo!

Ki te reo Māori e karanga nei

Whakarongo!

Ki ngā akoranga rangatira

Nā te Atua i tuku iho

Ki a tātou e

Pupuritia, kōrerotia mō ake tonu Tirohia!

Ngā tikanga tapu a ngā tīpuna

Kapohia!

Hei oranga ngākau auē

Whiua ki te ao, whiua ki te rangi

Whiua ki ngã iwi katoa

Kaua rawa ră e tukua e, kia memeha e

Whakarongo!

Ki te reo Māori e karanga nei

Whakarongo!

Ki ngā akoranga rangatira

Tēnā kia purea e te hau ora e

He kupu tuku iho mō tēnei reanga. Whakarongo!

Listen!

To the Mãori language which is saying Listen!

To the noble teachings

It was the Lord Almighty who bequeathed it

To us

Retain it! Speak it for all time!

Look!

The sacred customs of our ancestors

Reach out for them

As a source of pleasure

Then disseminate them to the world, to the heavens And to people everywhere

Never let these sacred customs wither and die.

Listen!

To the Mãori language which is saying

Listen!

To the noble teachings

Ritually purified by the life-giving winds

Let these words be a commandment to this generation Listen! 


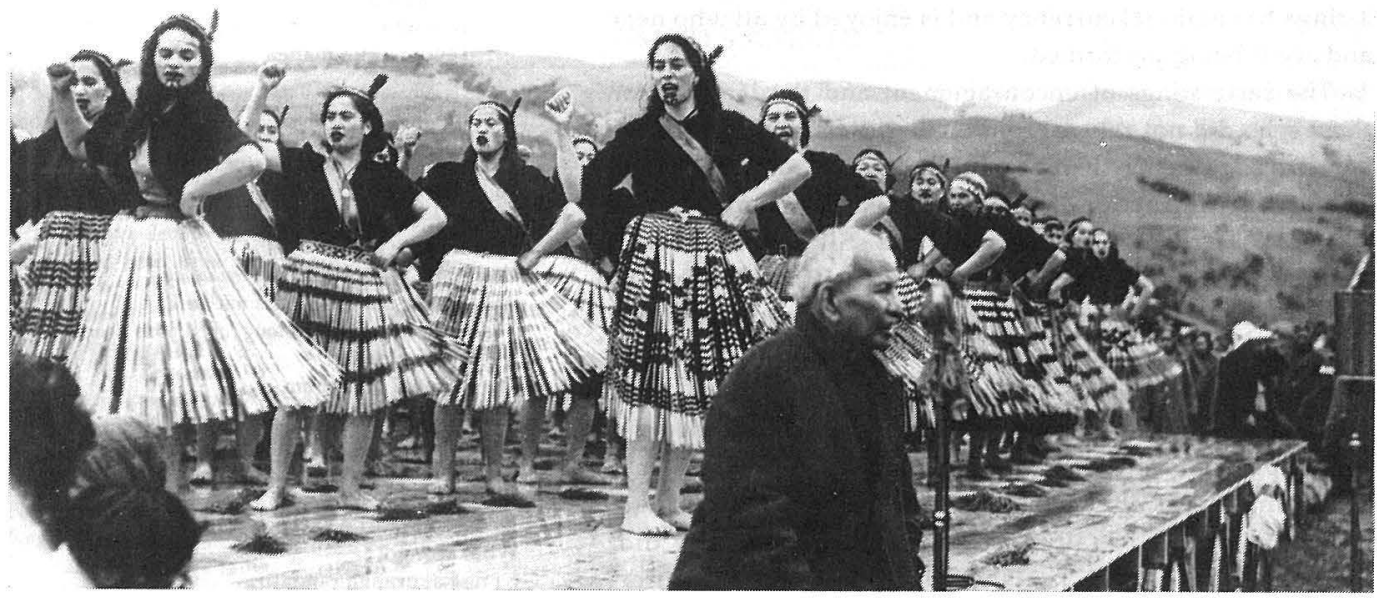

5. E Rere Pōwhiri

Nekenekehia!

Hei! Hā!

E rere pōwhiri!

Nāu rā, Te Ata-i-rangi-kaahu, te karanga

Haere mai, e hika mā

Te Whare Wānanga e tū atu nei

Ka kakapa te manawa

Aue!

Me pēwhea rā, e mau ai

Ngā wawata, e tau ai

Me huri rā, te kanohi

Me hoki mai ki te wā kāinga e

Aue!

Kei konei rā, te mauri

Kei ngā marae nei, taku kawa

Ngā maunga, taku ihi

Te papa whenua e takoto nei.

Be on the move!

Hei! Hā!

The invitation has been received!

The voice of welcome is yours, Te Ata-i-rangi-kaahu Bidding all to come

And so standing before you is Te Whare Wananga Hearts beating with joy

How is it possible

For us to realise our dreams?

Turn your gaze

To your own tribal territories

For it is there that the very essence of Māoridom survives

On the marae is my code of conduct

In the mountains my source of pride

$Y e s$, in the land lying here before me.
Sir Apirana Ngata (forefront), noted cultural leader and composer of waiata-ā-ringa, statesman and organiser of the hui for the VC investiture of Second Lieutenant Ngarimu at Ruatoria in 1943.

World War Two provided the occasion for the composition of many classic waiata-a-aringa. The illustration shows one of the groups which contributed to a four-hour programme of haka and waiata-āringa at the Ngarimu hui. Alexander Turnbull Library.

flames of the fire', as described in Mãori; songs were composed to seek divine intercession to ensure the well-being of the soldiers while they were away; songs were composed to mourn those who died on the field of battle and songs were composed to welcome home those fortunate enough to survive the war.

Some of the classics of the waiata-ā-ringa repertoire date from this period and are still performed today by the older generation though many of the young people do not know them. I consider them to be classics of the waiata-a-ringa repertoire because of the language employed and the manner in which the sentiments are expressed, particularly in the songs of Tuini Ngāwai, Sir Apirana Ngata and Wī Moana, composers whose songs enjoyed national popularity during, and well after, the war.

Perhaps the two best known songs of the time are 'Arohaina Mai' and 'E Te Hokowhitu-a-Tū', both composed by Tuini Ngāwai who was strongly of the conviction that if the young were to be attracted to waiata-ā-ringa that popular tunes of the time had to be used and then adapted to suit the lyric of the composer. All of Tuini Ngāwai's composi- 
tions are based on tunes that were popular. She felt such tunes were the appropriate vehicle for whichever sentiment she was wishing to express.

It should be stated that it is probably because of the employment of popular tunes of the day that many waiataa-ringa have been peremptorily dismissed. The audience has recognised a tune, mistakenly thought that the Māori lyric was a translation of the original, and therefore not given the Māori lyric the serious consideration that is its due. From World War Two onwards tunes have been borrowed, adapted and used as vehicles of expression for the Māori composer, that is, up until the beginning of the Aotearoa Festival of the Māori Performing Arts which began in 1972 and which has as one of its basic tenets that all tunes employed must be originally composed.

While many new songs contain original music in the period from 1972 to today, none of them has caught the imagination or enjoyed the currency that those of Tuini Ngāwai did, the exception being some of the compositions of her niece, Ngoi Pēwhairangi, whose songs were popular in the sixties and seventies, as were those of Kōhine Pōnika.

To return however, to the compositions of Tuini Ngāwai. Her song, 'Arohaina Mai', still very popular today, asks for the blessings of the Almighty on the Māori Battalion, exhorts the people at home to suppress all pain and sorrow and to retain the very essence of being Māori.

Her composition, 'E Te Hokowhitu-a-Tū' is a song of encouragement to the Māori Battalion urging them to fight on and enlist divine support. Part of the song is a lament for Te Moana-nui-a-Kiwa Ngārimu, who was awarded the Victoria Cross posthumously. Tuini Ngāwai, in fact, composed many songs in his memory.

When the Victoria Cross was awarded to the parents of Ngārimu, the song 'Hītara Waha Huka' (Example 2) was sung by all the schools in and around Ruatoria where the ceremony took place. Such songs as these afforded the people the opportunity to vent their spleen and to express their anger at the audacity of Hitler and Mussolini and for the casualties suffered by all the tribes.

Some of the most beautiful songs, lyrically, were composed to welcome home those fortunate enough to survive the war. None could be more representative of this genre than Sir Apirana's composition, 'Pōwhiritia' (Example 3).

The waiata-ā-ringa from the end of World War Two began an obsession with the loss of language and identity and this continued until well into the 1980s. Coupled with this was a more simple lyric with no classical or mythological allusions. Two of the dominant names of the time are Kōhine Pōnika and Ngoi Pēwhairangi, whose songs still enjoy great popularity.

The song used to highlight this year as Te Tau o te Reo Mãori is 'Whakarongo', composed by Ngoi Pēwhairangi (Example 4). And to illustrate the composing genius of Kōhine Pōnika, we have the song 'E Rere Pōwhiri' (Example 5).

\section{Taku Rātā Tū Tahi}

Hūtia ana te hei kaka piripiri, te hei mokimoki

I te kakī o te motu

Tēnei ka tū tahanga.

Kōrangirangi ana a manawa, nawe ana a ngākau

I te haehaenga a mate.

Me pēhea kē rā e mahea ake ai?

Me tuku ko whakaaro kia hoki

Ki ngā hōkio, ki ngā hoka

Ki ngā whakaohonga mauri, ki ngā whakataunga mauri

Ki ngā wā o te uruhau, ki ngā wā o te kiwakiwa

Kia riro ko te matawaia o te kamo

Ko te tārere o te roimata

Hei whakakite $\mathrm{i}$ te ngau kino o te aroha

$\mathrm{Ki}$ a koe, kei te whakamarumaru

$\mathrm{O}$ ia mahi e eke nei, e eke nei ki ōna tāpuhipuhi Hei rāhiri mā te marea

I aro o pae, i tua o pae.

Nā te momo i a koutou nā, a kore e wehi,

Ka tere te waka e hoea nei

Ko koe, te kaihautū, i te ihu

Ko ngā kapa haka, ngã kaihoe, i te kei

He wā ka pākokikoki, he wā ka paparōnaki

Ko tōu ake tino popore ia

Ko te reo! Ko te reo! Ko te reo!

Ko te kupu kia tika,

Ko te kupu kia hāngai,

Ko te kupu kia ita.

Nei rā tō ōhākī ki tō iwi

E whakamomori nei kia eke ki tāu i kī ai.

Te eke rānei, tē eke rānei?

E koro, e Matu, kei taku rātā tū tahi,

Takoto!

Sachets of scented piripiri and mokinoki

Have been torn from the throat of the people

Now bare.

The heart is saddened, the soul scarred

From death's assault

How can this pain be alleviated?

Let us cast a backward glance

To the low points and to the high

To the times of provocation, to the times of placation

To the times of joy, to the times of sorrow.

Let the tear-filled eyes

The tears that flow so copiously

$B e$ testament to the great affection

For you, the presiding figure

Over these activities which are reaching

Ever greater heights

And are admired and enjoyed by people

At home and abroad.

It was people such as you,

Those unafraid to state their opinions publicly,

Who inaugurated this festival.

You, the Chairman, stood to the fore

Performing groups to the rear lending their support.

There were times of dissension and times of accord

Your greatest concern was

The language! The language! The language!

The word should be correct,

The word should be apt,

The word must be retained.

This, then, is your bequest to your people

Striving to attain your desired goal.

Will or will it not be attained?

Matu, e koro, you my rātā once standing in solitary splendour

Rest in peace. 
7.

E koutou, e te aumangea

Kei hea koutou hei āki

I ngā hau kino o te wā?

I te wao tapu nui a Tăne

Urutapu ana, ururua ana, matomato ana

Te tipu mai o te kahikatoa

O te tōtara haemata

Nồ te hinganga, tūpapahū ana te whenua

Ka kore koutou kei hea he taunga

Mō te manu kaewa?

Kurupākara ana tērā te māra a Tāne

I te pekī, i te tîhau a ngā manu

Kua kore nei i tiu, kua kore nei i topa

Kia pātai noa ahau

Kei hea aku manu tioriori,

Aku manu taki, aku manu tāiko

I te kāhui e pōkaikaha nei

Aue! kia tioriori noa mai

Ko te manu

Kia kōkī, kia ketekete mai ano

Ko te kākā

Kia korihi mai anō

Ko te kōparapara

I te pūaotanga o te rā

Te tangi kau nei te mapu.

Tērā pea me kapo ko te mahara

Me kapo ko te kupu

Mã reira e tū mai anō ai he māhuri

E tiu anō ai

E korihi anō ai

Ngā manu o te wao.

You, my towers of strength,

Where are you to oppose

The negative element which assails us?

In the sacred forest of Tane,

In a nutural state, in the undergrowth, lush and green

Grew the kahikatoa

And the sturdy to tara

When felled, the earth resounded with their crashing

Without you, where is there a perch

For the wandering bird?

The garden of Tãne, once filled with the noise

Of the twittering and the chirping of the birds

Are no longer able to soar and swoop

Thus causing me to ask,

Where are my sweet sounding birds,

My sentries who guarded the flock

Now confused, now unsettled?

Ah me! If only the birds would sing sweetly once more,

If only the kākã would once again sing and chatter,

If only the bell-bird would again sing

At the dawning of a new day

How I do mourn you all.

Perhaps one should keep their memory alive

And remember what they had to say

Thereby will rise

Another sapling, another sturdy tree

And the birds of the forest

Will once more soar and sing
To return to the Aotearoa Festival of the Mãori Performing Arts and its insistence that waiata-ā-ringa be performed with tunes originally composed rather than employing the tunes of songs popular at the time. Perhaps, one of the negative aspects of this decision has been that while many such songs have been composed none has enjoyed national popularity as have those of Ngoi, Tuini, Kōhine and other earlier composers.

The language of many of the contemporary compositions is not as critical, not as apt nor as interesting as that of the composers of the war period. As the language is spoken less and less so the lyrics of the contemporary waiata-ā-ringa become more ordinary and, in many cases incorrect, even allowing for so-called poetic licence!

To say that nothing of note, lyrically, has emerged would be unfair as many composers have resorted to classical modes of expression particularly in songs expressing sadness at the loss of people such as Ngoi Pēwhairangi, John Rangihau, Sir James Hēnare, Sir Kīngi Ihaka, Sir Mōnita Delamere, Hamuera Mitchell and many others of our cultural icons whose contribution to the survival of the language and the performing arts has been immeasurable.

To exemplify the language of a recent composition is the lament (Example 6) for Sir Kīngi Ihaka who died in early 1992.

And to show the more classical use of imagery in a waiataâ-ringa, Example 7, is also a lament, for the many great people who have passed on. It is a recent composition, 1993, and was the winning entry in the 1994 waiata-ā-ringa section of the Festival of the Māori Performing Arts held in Hāwera in February, 1994.

It will be seen that despite my misgivings there is really no reason, logically, why waiata-ā-ringa cannot become the classical waiata of the new century except that the present generation is more conservative, culturally, than that of its parents or grandparents. I doubt that this generation of young Mãori will allow classical waiata to be replaced by waiata-â-ringa on the more formal occasions for it is the generation that insists that waiata be sung. It is also this generation that is learning waiata to ensure that waiata are retained. It is a generation which brooks no compromise, culturally - it insists on things being correct.

Some waiata have already been lost for all time but an arrest in their decline is being made and with some success.

Certainly in my time waiata-ā-ringa will never replace classical waiata except in those areas where such has been the practice for the past two generations.

Most tribes are looking to their classical waiata because of pressure from their young people and while that pressure is sustained and maintained waiata will continue to be sung on the more important occasions and, as a consequence, will survive well into the new millennium, perhaps never to be replaced by the poor relation of the Mãori dance repertoire, the much maligned, little appreciated, waiata-ā-ringa. 